of removal costs, ${ }^{29}$ injury to going-concern value, good will and contract losses, the difference between reasonable-use value and the cost of other similar premises and the value of any other property rights injured as a result of the condemnation. Such a test would exclude any payment for sentimental attachment to the property, psychological disorders incurred because of the condemnation, excessive removal costs, ${ }^{30}$ and other claims which are likely to induce fraud or are so speculative that any attempt at a valuation would be a blind guess.

The cost of paying for property seized for public use should be shared equally by all the taxpayers. The Fifth Amendment was not meant to be a subsidy of the community by the individual.

\title{
INFORMAL CONDEMNATION AND THE REVIVAL OF THE CRESS CASE
}

In recent years there has been a trend toward increased federal immunity to claims by riparian owners on tributaries of navigable streams for damages resulting from federal flood control activities. The case of United States $v$. Kansas City Life Insurance Co. ${ }^{2}$ may well be considered a reaction against this trend. Respondent's farmland, located on a non-navigable tributary one and one-half miles from the Mississippi River, was rendered unfit for agricultural purposes by a stoppage of drainage due to the raised level of the tributary. This was the result of the construction of a dam by the federal government on the Mississippi. ${ }^{3}$ Two issues were recognized by the majority: (I) May the government permanently raise a navigable stream to its ordinary high water mark without liability for damage to property beyond the bed of the stream; and (2)

29 One authority states that "it would seem that compensation for the cost of removal to a new site, within a reasonable distance, might be worked out in favor of the owner of the land by use of the doctrine that where only part of the land is taken, the measure of compensation is the difference between the value of the entire property before the taking and the value after the condemnation of the part not taken. Under this theory, the owner would recover the value of the land and improvements, less the value of the improvements required to be removed. Of course, this deduction would be diminished by the fact that the value of the improvements would be no greater than what they were after subtracting the cost of making them usable by moving them to a new location." McCormick, op. cit. supra note ro, at 947.

${ }^{3 \circ} \mathrm{A}$ person living in Chicago could not receive removal costs to California.

See Justice Douglas' dissent in United States v. Kansas City Life Insurance Co., 339 U.S. 799, 812 (r950); Frank, The United States Supreme Court: 1949-50, I8 Univ. Chi. L. Rev. I, I5-I8 (1950); Federal Eminent Domain Power in the Development of Water Projects, 50 Yale L.J. 668 (r94I); Fitts and Marquis, Liability of the Federal Government and its Agents for Injuries to Private Property Resulting from River Improvements, I6 Tenn. L. Rev. 80I, 813-24 (r94r).

339 U.S. 799 (I950). Justices Black, Douglas, Minton and Reed dissented.

3 Respondent's $I, 7$ Io acres on Dardenne Creek were destroyed by lack of drainage because of the raised level of the creek, although the Mississippi did not rise above the ordinary high water mark. The Court of Claims awarded \$22,519.60 with interest since r9.38. 
was the particular destruction a taking of property within the meaning of the Fifth Amendment to the United States Constitution?4 On both, the Court found for the respondent-owner. For purposes of analysis, the issues will be discussed simultaneously; to answer the question of what types of damage are compensable, the location of the damage must necessarily be considered.

For present purposes, the history of the concept of taking within the area of navigable streams and their tributaries began with the Fifth Amendment, which states that property shall not be taken for public use without just compensation. It soon became apparent, however, that the federal government had a special control over navigation, ${ }^{5}$ and therefore, over navigable streams. ${ }^{6} \mathrm{Al}-$ though this control was not considered an absolute title, it was in the nature of a dominant interest. ${ }^{7}$ This theory, it was held, eventually freed the government from payment for destruction of property which lay in the bed of the navigable stream below the ordinary high water mark $;^{8}$ damage done below

4 "[N]or shall private property be taken for the public use without just compensation." U.S. Const. Amend. 5.

$s$ Gibbons v. Ogden, 9 Wheat. (U.S.) I, I89 (I824). As indicative of the difference in judicial attitude toward the application of the Fifth Amendment to navigable streams and to other areas of eminent domain, see Justice Douglas' opinion for the Court in United States v. Causby, 328 U.S. 256 ( 1946 ), and his dissent in United States v. Kansas City Life Insurance Co., 339 U.S. 799, 8I2 (I950). In the former he said, at 26I, "It is the owner's loss, not the taker's gain which is the measure of the value of the property taken." Damages were awarded for chickens frightened to death by low flying warplanes. But in the latter case he said, at $8 \mathrm{r}_{3}$, "[N]o vested private right is given to anyone, as against the public interest, in the full utilization and control of the river's bed for navigation or in the flow of the stream within it."

6 "Commerce includes navigation. The power to regulate commerce comprehends the control for that purpose and to the extent necessary, of all the navigable rivers of the United States. ... For this purpose, they are the public property of the nation, and subject to all the requisite legislation by Congress." Gilman v. Philadelphia, 3 Wall. (U.S.) 7I3, 724 (I865). See South Carolina v. Georgia, 93 U.S, 4, 10 (1876). But cf. Yates v. Milwaukee, to Wall. (U.S.) 497 (I87o).

7 "[A]lthough the title to the shore and submerged soil is in the various states, and individual owners under them, it is always subject to the servitude in respect of navigation created in favor of the federal government by the Constitution." Gibson v. United States, I66 U.S. 269, 272 ( 1877 ). Consult Scranton v. Wheeler, I79 U.S. I4I (I900), for a keen analysis by Justice Harlan of the cases dealing with the nature of federal control of navigable streams. Both this and the Gibson case deal with private owners losing accessibility to the water.

${ }^{8}$ United States v. Chicago, M., St. P., \& P. Ry. Co., 3 I2 U.S. 592 (I94I). Prior to this case, in United States v. Chandler-Dunbar Water Power Co., 229 U.S. 53 (Ig13), the Court held that the Federal Government "may require [the structures'] removal and forbid the use of the bed of the river by the owner in any way which, in its judgment, is injurious to the dominant right of navigation"; hence, private ownership, granted by the state in this area, is a mere qualified title.

Justice Harlan, speaking for the Court in Philadelphia Co. v. Stimson, 223 U.S. 605 (IgII), said, at 629, "[T]he absolute title of the riparian proprietor extends [down] to high water mark only, and ... between ordinary high and ordinary low water mark, his title to the soil is qualified." Compare Willink v. United States, 240 U.S. 572, 580 (rgI6) (order to vacate a wharf within harbor lines); Greenleaf-Johnson Lumber Co. v. Garrisson, 237 U.S. 25I, 268 (r9I5) (destruction of wharf outside new harbor lines but within old ones); Lewis Blue Point Oyster Cultivation Co. v. Briggs, 229 U.S. 82, 85 (I9r3) (government destruction of oyster beds below ordinary high water mark); Union Bridge Co. v. United States, 204 U.S. 364,400 (I906) (required state authorized bridge to be modified at great expense). 
this mark was not a "taking" for public use. Where compensation was not required by the Fifth Amendment, a claimant was precluded from recovery on any basis. ${ }^{9}$ At common law a sovereign need not allow itself to be sued-the tradition is long.

The first major case which defined the limits of the government's dominant interest in the bed of the navigable stream was Pumpelly v. Green Bay Canal Co. ${ }^{\text {xo }}$ wherein it was held that an overflow of riparian land by flooding, above the water's "ordinary level"

Another early limitation on the government's dominant interest was United States v. Lynah. ${ }^{12}$ In that case there was considerable doubt whether the damage was caused by blockage of drainage or by overflowing. ${ }^{13}$ Since it was due, at least in part, to overflowing, plaintiff was allowed to sue under the Tucker Act, ${ }^{14}$ which permits contract actions against the government. The Court found an implied intent by the government to pay for damage amounting to a taking. ${ }^{15}$ In Horstman v. United States ${ }^{16}$ the application of this implied contract doctrine seemed to be limited to situations in which flooding had occurred. An unexpected percolation had flooded a large area located a considerable distance from the river, and since it was impossible to foresee this consequence, no implied intent could be found. In the absence of an implied contract compensation under the Fifth Amendment was denied.

Thus, where damage was the result of overflowing, compensation was awarded. But distinguishing the situations of overflowing, the Court refused to grant compensation where damage was the result of percolation and temporary intermittent flooding. ${ }^{77}$ These two forms of damage were held to be merely

9 Keokuk Bridge Co. v. United States, 260 U.S. I25 (I922). No award would be made on a tort claim.

${ }^{10}$ I3 Wall. (U.S.) 166 ( $187 \mathrm{r}$ ).

xI "Ordinary level" may be synonymous with ordinary high water mark; see ig Words \& Phrases 435, 437 (r940); 30 Words \& Phrases 253 (r940). In High Bridge Lumber Co. v. United States, 69 Fed. 320 (C.A. 6th, I895), the court recognized that permanent flooding was compensable; in addition they cited Transportation Co. v. Chicago, 99 U.S. 642 (I878), for authority that "indirect" encroachment on private riparian property on navigable streams may be compensated only when there is permanent flooding, and where other forms of destruction occur, damages should not be awarded. See United States v. Great Falls Mfg. Co., II2 U.S. 645 ( 1884 ).

12 I88 U.S. 445 (I902). But compare Tempel v. United States, 248 U.S. I2I (I9I7) (plaintiff failed to establish an implied contract where property was clearly within the government's right to improve navigation); Hill v. United States, 149 U.S. 593 (1893).

${ }_{23}$ The Court distinguished Mills v. United States, 46 Fed. 738 (D.C. Ga., I89r) because the damage there was caused by blocking of drainage rather than by overflowing.

${ }^{24} 62$ Stat. 940 (1948), 28 U.S.C.A. \$ I49I (1950).

15 The Lynah case was later overruled in United States v. Chicago, M., St. P., \& P. Ry. Co., 312 U.S. 592,598 ( $194 \mathrm{r}$ ), because in the former the damage occurred below the high water mark of a navigable stream. Washing away of land as a result of flooding is a taking as well as the flooding itself. United States v. Dickinson, 33I U.S. 745 ( 1947 ).

${ }^{16} 257$ U.S. I38 (I92I), following Tempel v. United States, 248 U.S. I2I (I9I7).

${ }_{77}$ Bedford v. United States, I92 U.S. 2 I7 (I903), was distinguished from the Iynah case because there was only percolation. Damage was an "incidental consequence" of the govern- 
consequential to the exercise of the government's dominant interest over navigable streams. ${ }^{x}$

The nature of a taking took a new turn in the leading case of United States $v$. Cress. ${ }^{19}$ The Court reiterated the doctrine that property in the bed of a navigable stream was subject to the exercise of the public right of navigation. ${ }^{20} \mathrm{It}$ then discussed overflow beyond the natural stage of the river as a taking, ${ }^{2 x}$ but after distinguishing the consequential injury cases where there were no "direct invasions," ${ }_{22}$ looked to the state law of Kentucky, and held that damage to a mill, destruction of a ford, and inevitably recurring flooding on a nonnavigable tributary, due to constructions on a navigable stream, were compensable takings.

What appeared to be a general extension of the concept of a "taking" as developed in the earlier cases was limited in United States v. Chicago, M., St. P., \& $P . R . C_{0.33}$ to situations where damage occurred beyond the ordinary high water mark. Plaintiff's tracks and telegraph poles were located on the banks of a navigable stream below ordinary high water mark and the Court refused to award damages for the overflow. Immunity for the government below ordinary high water mark may be interpreted to include the tributaries as far as such a permanent raising on the navigable stream to ordinary high water mark would go; thus limiting the Cress case only to those areas beyond this line. On the other hand, the rule may be confined to the bed (banks?) of the navigable stream and not affect the Cress doctrine as to tributaries. Because of this confusion, uncertainty also developed as to what kind of damage beyond the area of the government's dominant interest was compensable. While it was clear that compensation would be awarded for overflow, ${ }^{24}$ and that no award would be made for a mere loss of accessibility, even though there was a drop in the market value, ${ }^{25}$ still, there was a twilight zone where damage was caused by other means..$^{26} \mathrm{It}$ is generally accepted that compensation for damage, other

ment constructions; hence, not a taking. Compare Sanguinetti v. United States, 264 U.S. I46 (I924) (intermittent flooding); Horstman v. United States, 257 U.S. I38 (I92I); Cubbins v. Mississippi River Comm'n, 24I U.S. 35I (Igr6); Hughes v. United States, $23 \circ$ U.S. 24 (I9I3) (overflow by making a new levee); Jackson v. United States, 230 U.S. I (Igr3); Gibson v. United States, I66 U.S. 269 (I897); Transportation Co. v. United States, 99 U.S. 635 (x878). Consult Coleman v. United States, $x 81$ Fed. 599, 60I-3 (D.C. Ala., Igro), for a discussion of partial flooding; Atchley v. TVA, 69 F. Supp. 952 (Ala., 1947), on destruction of crops. Compare United States v. Welsh, 217 U.S. 333 (I9I0); United States v. Grizzard, 219 U.S. I80 (I9IO). For review of the cases consult Franklin v. United States, IOI F. 2d 459 (C.A. 6th, I939); Goodman v. United States, 28 F. Supp. 497, 50I-3 (Iowa, I939).

${ }^{28}$ See text at note 7 supra.

I9 243 U.S. 3 I6 (x9I6).

20 Ibid., at 320.

22 Ibid., at 324 .

2I Ibid., at 327 .

${ }^{23} 3$ I2 U.S. 592 (I94I).

${ }_{24}$ Pumpelly v. Green Bay Canal Co., 13 Wall. (U.S.) 166 (187r).

${ }^{25}$ Scranton v. Wheeler, x79 U.S. I4I (x900); Gibson v. United States, $x 66$ U.S. 269 (I896).

${ }^{26}$ Pumpelly v. Green Bay Canal Co., I3 Wall. (U.S.) I66 (I87I). 
than permanent overflow, is not granted where damage is done on the banks of navigable streams. ${ }^{27}$

In Franklin v. United States, ${ }^{28}$ a decision rendered in the Court of Appeals for the Sixth Circuit, the Cress case was not followed for lands bordering navigable streams. The lands here were above the ordinary high water mark under either interpretation of the Chicago case. Franklin's land was on high ground above the Mississippi River. The channel was diverted by the government from the west side to the east side of the river in aid of navigation; this almost completely destroyed Franklin's land. The court said the damage was a mere consequence of a lawful act of the United States and refused to grant compensation, saying that there must be a physical invasion; the character of the invasion, not the extent of damage, was the proper basis for relief. The Franklin case seems to indicate that the government is immune to claims for a "taking" of land on navigable streams as long as the level of the water remains below the ordinary high water mark. The Supreme Court refused certiorari of the Franklin case and was content to allow the Cress case to be disregarded where damage above the ordinary high water mark on a navigable stream was in issue.

The decision in United States v. Willow River Power Co. ${ }^{29}$ so limited the Cress case as to practically destroy its usefulness as precedent. The impaired efficiency of the plaintiff's water-power plant, located on a nonnavigable channel, a few rods from the navigable St. Croix River, was caused by waters backed up by a government dam on the navigable stream. The Court distinguished the Cress case by saying that the plaintiff's harm in that case was due to the raising of the waters on the tributary, whereas in the Willow case the damage was caused by the tail waters of the raised St. Croix flowing into the channel. Justice Roberts, dissenting, could see no justifiable distinction between the two cases and stated that the Cress case had been "disregarded or overruled." ${ }^{\circ}$ Indeed it seemed that the only tangible difference between the two cases was the difference in the distance of the land from the navigable stream.

The Kansas City decision was based on the fact that the destruction by percolation occurred on land located beyond the bed of the stream. ${ }^{3 x}$ However, the Court failed to indicate whether it meant to rule only concerning the destruc-

27 Where land on a navigable stream was damaged by blockage of drainage, the Court said that the Cress case was difficult to distinguish, "but we think it ought not to be taken as a precedent ... . for all the damage to all the lands near the river and the creeks leading into it, which have been made wetter, but not overflowed at any time, by the raising of the water."

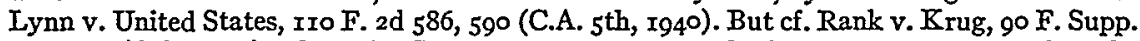
773,799 (Cal., I950), where the Cress case was used as authority to grant compensation; the damage to riparian owners on a navigable stream was caused by the government diverting waters out of the bed of the navigable stream.

${ }^{28}$ Ior F. 2 d 459 (C.A. 6th, 1939).

${ }^{29} 324$ U.S. 499 (I944).

${ }^{30}$ Ibid., at 514. See 45 Col. L. Rev. 792, 794 (I945), noting United States v. Willow River Power Co., 324 U.S. 499 (I944).

${ }^{3 x} 339$ U.S. 799, 8 I0 (I950). 
tion on a nonnavigable stream, but above the mark measured by raising the navigable stream to ordinary high water mark; or whether it also meant to include destruction of land located above the ordinary high water mark on a navigable stream. If it included the latter, then the effectiveness of the Horstman and Franklin cases and Lynn v. United States, ${ }^{32}$ all concerning damage on navigable streams, has been minimized. It appears, then, that only the former situation could have been meant. If this is the case, the Court is reaffirming the doctrine of the Cress case-that damage other than total destruction beyond the area of the government's dominant interest on nonnavigable tributaries, is compensable.

Recent developments in related areas indicate that there is no disposition to limit federal control to streams which are navigable in fact. In United States $v$. Appalachian Power Co.33 the Court stated that the test of navigability had changed from a navigability "in fact" doctrine 34 to a consideration of the river's availability for navigation; ${ }^{35}$ it is not necessary that the river be navigable continuously in space or time..$^{36} \mathrm{In}$ addition, federal power over navigable streams is not limited solely to navigation, but extends to such activities as flood control.

This case prompted Justice Douglas, speaking for the majority in Oklahoma ex rel. Phillips v. Atkinson Co.,37 to say, "and we now add that the power of flood control extends to the tributaries of navigable streams. For just as control over the nonnavigable parts of a river may be essential or desirable in the interests of the navigable portions, so may the key to flood control on a navigable stream be found in whole or in part on its tributaries." ${ }^{38}$ This would seem to indicate that the commerce power which the government enjoys over navigable streams should be extended to the tributaries if it is for the improvement of the navigable stream.

Indicative of the scope of Justice Douglas' opinion in the Atkinson case, is his strong dissent in the Kansas City case: "Because water seeks its own level,

${ }^{32}$ I Io F. 2d $5^{86}$ (C.A. $5^{\text {th }}$ 1940); see quotation note 27 supra.

33 III U.S. 377 (I940).

34 Ibid., at 406; cf. The Daniel Ball, ro Wall. (U.S.) 557 (I870); The Montello, Ir Wall. (U.S.) 4 II (I87O).

${ }^{35} 3$ II U.S. 377,407 (x940). Accord: United States v. Oregon, 295 U.S. I, I5 (I935). But see United States v. Rio Grande Irrigation Co., 174 U.S. 69o, 699 (I899).

${ }^{36} 3$ II U.S. 377, 409. Compare United States v. Utah, 283 U.S. 64 (I93I); Arizona v. California, 283 U.S. 423 (I93I). In United States v. Chandler-Dunbar Water Power Co., 229 U.S. 53 ( $\mathrm{rgr}_{3}$ ), the Court upheld a congressional determination of navigability. But compare United States v. Gerlach Live Stock Co., 339 U.S. 725 (1950), where compensation was awarded because of the intent of Congress that the project was reclamatory rather than navigable.

${ }^{37} 3^{13}$ U.S. 508 (I940). It was held that the building of a dam on a nonnavigable portion of the Red River for flood control was a valid exercise of the commerce power of the United States.

${ }^{38}$ Ibid., at $5^{25}$. 
raising the level of the river necessarily raises that of the tributary at their conjuncture and as far upstream as the effects of the lifting may go. These facts are equally apparent to both types of owners. We think they should be anticipated by both, and that the one has no more power to obstruct or burden the power of Congress in its control of the river's bed in the interest of navigation than the other." 39

Justice Douglas would apply the ordinary high water mark rule to that part of the bed of the nonnavigable tributary that is affected by the raising of the navigable stream to ordinary high water mark and thus allow "change in the natural flow to the extent of lifting the mean level to high water mark without liability for constitutional compensation." 40

The effect of the Kansas City decision is to shift from the individual riparian owners to the government a greater burden of the costs of federal river projects. It is arguable that this greater cost should be spread among all the national taxpayers. On the other hand, it may be that the necessity for increasing Congressional appropriations for such river developments induced Justices Black, Douglas, Minton, and Reed to dissent. They argue that riparian owners on navigable and non-navigable streams should be treated alike since "[n]either has any greater right to have the river flow in its natural state than the other." "4x The present Court appears unwilling to adopt such a view of federal power and restricts the doctrine of federal immunity to the area below the ordinary high water mark on navigable streams.

If the doctrine of immunity against landowners within the bed of the navigable stream was originally justified under the commerce clause, ${ }^{42}$ it would seem that the same reasoning would grant this immunity on the tributaries of the navigable stream. It is difficult to understand why the Court has balked.

\section{LUNACY AND IDIOCY-THE OLD LAW AND ITS INCUBUS}

The law pertaining to the insane embodies a most peculiar paradox. On the one hand, it is gradually being realized that our concept of "insanity" should be revised and reworked in accordance with new psychological learning. On the other hand, insanity as a defense in criminal trials, the field where the problem is most acute, is used in a loose and unscientific manner, the test being phrased in terms of "knowledge of right and wrong." This note will attempt to shed some light on the causes of this situation by an examination of the origins and early development of the legal doctrines relating to the insane.

The central distinction employed by the old law was between the "lunatic" and the "idiot." The lunatic was subject to fits of madness, with lucid intervals

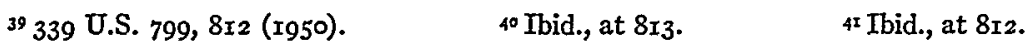

42 Compare Leovy v. United States, I77 U.S. 621, 632 (I900). 